\title{
As Directed
}

National Cancer Institute

\section{Source}

National Cancer Institute. As Directed. NCI Thesaurus. Code C64619.

Indicates that a drug or therapy should be used as specified by the prescribing physician. 